\title{
MACROPHYTE MODEL FOR A TROPICAL GLACIER RIVER IN THE BOLIVIAN ANDES
}

\author{
Evelin HUMEREZ1 ${ }^{1}$ and Makoto UMEDA ${ }^{2}$ \\ ${ }^{1}$ Student member of JSCE, Dept. of Civil and Environmental Engineering, Graduate School of Engineering, \\ Tohoku University (Aoba-yama 6-6-06, Sendai, 980-8579, Japan) \\ ${ }^{2}$ Member of JSCE, Associate Professor, Dept. of Civil and Environmental Engineering, Graduate School of \\ Engineering, Tohoku University (Aoba-yama 6-6-06, Sendai, 980-8579, Japan)
}

\begin{abstract}
The objective of this research is to develop a macrophyte model for the growth of submerged aquatic vegetation in the Condoriri River. The processes included in the macrophyte model are: photosynthesis, dark respiration, excretion and non-predatory mortality. The influence of the nutrients, the discharge, solar radiation, and the water temperature on the growth of the aquatic plants was considered. Macrophyte biomass and the specific nutrient transport of TN $\left(0.02 \mathrm{~g} \cdot \mathrm{s}^{-1} \cdot \mathrm{km}^{-2}\right)$ and TP $\left(0.0035 \mathrm{~g} \cdot \mathrm{s}^{-1} \cdot \mathrm{km}^{-2}\right)$ were greater during the wet season than during the dry season. Good agreements were achieved between field measurements and the model predictions of macrophyte biomass. The proposed model predicted seasonal changes in the growth of the aquatic plants, despite their high spatial and temporal variations.
\end{abstract}

Key Words : Condoriri glacier, macrophyte biomass, nutrients, specific transport

\section{INTRODUCTION}

Among the many factors that influence water quality, submerged aquatic plants may contribute significantly to the productivity of rivers, lakes and reservoirs. Their growth and decomposition influence biotic and abiotic components of the ecosystems. Physical factors (e.g. temperature, irradiance levels, and discharge) and physiological characteristics of the plant (e.g. nutrient requirements from water and sediments) control the growth of the aquatic macrophytes ${ }^{1)}$.

Several research groups have produced simulation models for the growth of submerged macrophytes ${ }^{2}$. Numerous simple phosphorus models were developed with the assumption that primary trophic response of a water body to its nutrients would manifest in the form of phytoplankton, rather than aquatic macrophytes ${ }^{3}$.

Studies have rarely been oriented towards obtaining information on macrophyte modelling in tropical rivers. Nonetheless, simulation of the macrophyte growth seems a far less popular topic in aquatic vegetation science in the Andes aquatic ecosystems. Predictions on the macrophyte biomass in the Bolivian glaciers rivers remain unreported.
Researches are needed in order to understand the present conditions of the aquatic vegetation in the glacial rivers and lakes, and the influence of nutrients and physical parameters. Generating this knowledge base is pertinent for the management of water resources in the future.

In the Central Andes, $80 \%$ of the freshwater sources originate from the mountainous regions, affecting ecosystems and population downstream ${ }^{4}$. Many cities located above $2500 \mathrm{~m}$ depend almost entirely on high-altitude water stocks. Therefore, we focused on the Condoriri Glacier and its basin, which provides about $44 \%$ of drinking water to the two major cities in Bolivia (La Paz and El Alto). Furthermore, the watershed displays rich aquatic ecosystems, composed of rivers, lakes and wetlands.

Therefore, the aim of this research is to develop a macrophyte model for the growth of the submerged aquatic vegetation in the Condoriri River. Influential factors such as nutrients in water and sediments, the variation of the discharge, solar radiation, and the water temperature were considered. Field measurements were conducted to determine variations on discharge, macrophyte biomass, water temperature, and nutrients in water and sediments during both dry and wet seasons. 


\section{MATERIALS AND METHODS}

\section{(1) Study area and meteorological conditions}

Condoriri River basin has an area of $22.6 \mathrm{~km}^{2}$, located 37 kilometers northwest of La Paz city in Bolivia. It is situated between $4400 \mathrm{~m}$ and $5522 \mathrm{~m}$ above sea level, in the Central Andes. The river originates from the Condoriri Glacier and the Little Alpamayo Glacier, on the upper most reaches of the basin. Fig.1 shows the map containing the sampling points of this study. The Condoriri River basin is composed of the mainstream and three lakes (Khellual Khota, Chiar Khota, and Kallan Khota). The submerged aquatic vegetation in the Condoriri River is mainly composed of macrophytes and small amounts of periphyton and phytoplankton.

Measurements of meteorological conditions such as precipitation and solar radiation were carried out in the Condoriri River basin ${ }^{56)}$. These parameters were measured at a meteorological station close to P4. By analyzing the measured data, we obtained the seasonal characteristic of the basin. The Condoriri River watershed is characterized by a marked seasonality of precipitation between wet seasons (September-April) and dry seasons (May-August) ${ }^{7}$. The total precipitation during wet and dry seasons was $624 \mathrm{~mm}$ and $19 \mathrm{~mm}$, respectively, based on the observations from September 2011 to August 2012. During the wet season, frequent precipitation occurs as often as 15 days/month with a daily average of $5.5 \mathrm{~mm}$. On the other hand, there were only eight rainy days during the four months of the dry season. The average

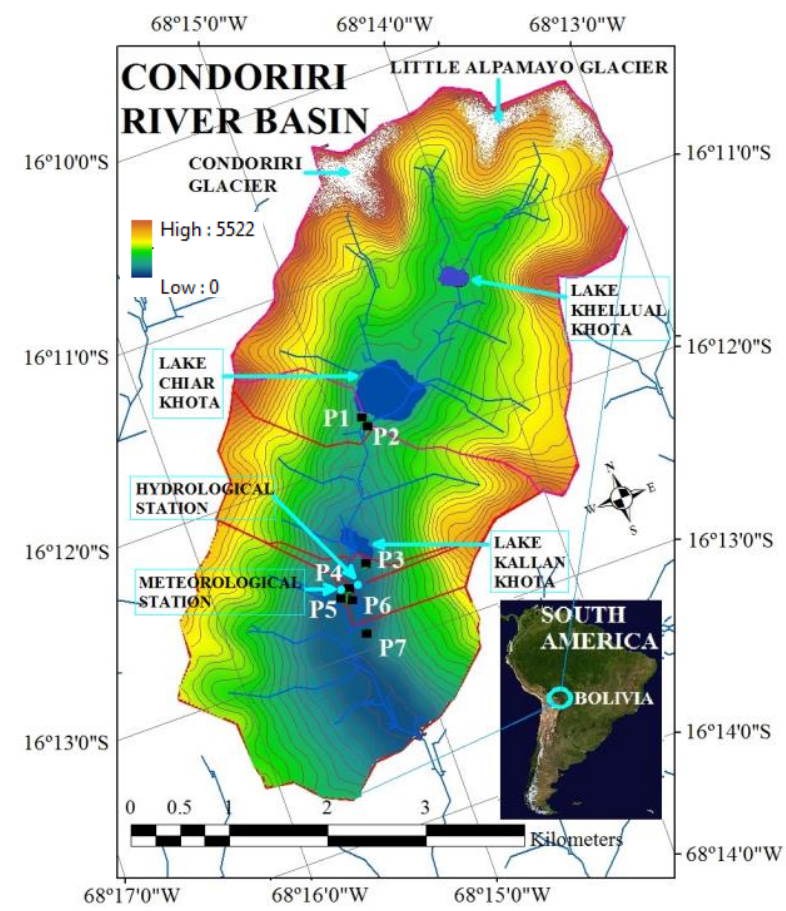

Fig.1 Field measurements of the Condoriri River basin Elevations from 4400 m.a.s.l. values of solar radiation during the dry season and wet season were $510.6 \mathrm{~W} \cdot \mathrm{m}^{-2}$ and $384.3 \mathrm{~W} \cdot \mathrm{m}^{-2}$, respectively.

\section{(2) Field work and analysis}

Seven sampling points were set in the Condoriri River (P1-P7) as shown in Fig.1. The field work was conducted to measure temperature in the stream water and to take samples of water and aquatic plants from the main river. This was repeated at the same locations during the dry (July, 2012 and August, 2013) and wet (February, 2013) seasons. Water temperature was measured using a multi-parameter portable water analyzer (Multi 3420, Xylem).

The discharge was measured for the estimation of the transport of nutrients in the river at each monitoring point. A hydrological station was equipped with a $\mathrm{HOBO}$ piezometer and a $\mathrm{HOBO}$ onset data logger (HOBO U20-001-01) at P4. The station recorded the atmospheric pressure, absolute pressure and water temperature with a 10 minutes temporal resolution. The hydrostatic pressure was estimated by the difference between the absolute and the atmospheric pressures. The hydrostatic pressure was converted into water depth and the water depth into discharge according to calibrated rating curves developed in a previous study ${ }^{6}$. The specific discharge and specific transport of nutrients were obtained from the catchment area, the discharge and the nutrient concentrations at each point.

For the analysis of total nitrogen (TN) and total phosphorus (TP), a $50 \mathrm{ml}$ aliquot of unfiltered water sample was stored in a plastic bottle previously washed with water sample. The samples were transported and stored at $4{ }^{\circ} \mathrm{C}$ in order to prevent biological reactions. TN and TP were measured using a TN-TP auto-analyzer (SWAAT, BL TEC K.K.) For the determination of the biomass, macrophytes were harvested from a quadrat of $50 \times 50 \mathrm{~cm}^{2}$ by hand ${ }^{8}$, from all the monitoring points (P1 to P7) in July (2012), February (2013) and August (2013). In the laboratory, plants were cleaned, separated by species, dried to constant mass (at $40^{\circ} \mathrm{C}$ ) and weighed. In order to estimate the total area of vegetation coverage in the river, we roughly measured the area of the aquatic plants along the river. The analysis of nitrogen and phosphorus in sediments were carried out using the methodology proposed by the International Soil Reference and Information Centre (ISRIC) ${ }^{9}$.

\section{(3) The macrophyte model}

The macrophyte model in this study mainly deals with the submerged group of macrophytes and does 
not differentiate plant parts or species. Data obtained in July 2012 was taken as model initial conditions for the predictions of macrophyte biomass.

\section{a) Macrophyte equation}

The proposed model equation for macrophyte biomass is given below:

$$
\frac{d M}{d t}=(P-R-E-N) M
$$

where $M$ represents the macrophyte dry weight biomass $\left(\mathrm{g} \cdot \mathrm{m}^{-2}\right) ; t$ is time (d); $P, R, E$ and $N$ represent gross production rate $\left(\mathrm{d}^{-1}\right)$, respiration rate $\left(\mathrm{d}^{-1}\right)$, excretion rate $\left(\mathrm{d}^{-1}\right)$ and death rate $\left(\mathrm{d}^{-1}\right)$, respectively.

\section{b) Gross production rate}

The daily photosynthetic or gross production rate $P$ depends on water temperature $(T)$, light intensity $(I)$, nutrient concentrations $\left(C_{i}\right)$, and the effective maximum photosynthetic rate:

$$
P\left(T, I, C_{i}\right)=P_{\max } T_{i}(T) L_{i}(I) O_{i k}\left(C_{i}\right)
$$

where $T_{i}$ is the temperature limitation function, $L_{i}$ is the light limitation function, and $O_{i k}$ is the nutrient limitation function. $P_{\max }$ is the maximum gross production rate ${ }^{1)}$.

Temperature has an important effect on aquatic plant life. The Hill function describes the temperature dependence of photosynthesis. The coefficients were obtained from experiments at temperate temperatures and applied in macrophyte modelling 10)11)12). Temperature limitation is calculated by:

$$
T_{i}(T)=\frac{1.35 T^{3}}{T^{3}+14^{3}}
$$

where $T$ is the water temperature in ${ }^{\circ} \mathrm{C}$.

Irradiance levels are of great importance for aquatic plants growth. Macrophyte photosynthetic rates increase with increasing levels of light to a maximum level, beyond which the rate decreases. Light limitation is calculated by

$$
L_{i}(I)=\frac{I}{I+H_{i}}
$$

where $L_{i}$ is the light limitation factor, $I$ is the solar radiation $\left(\mathrm{W} \cdot \mathrm{m}^{-2}\right)$ and $H_{i}$ is the half saturation light limitation constant obtained by experimentation ${ }^{2}$.

The Michaelis-Menten equation well describes the kinetics of nutrient uptake and is used in the gross production equation to determine nutrient limitation $O_{i k}$ :

$$
O_{i k}\left(C_{i}\right)=\frac{C_{i}}{K+C_{i}}
$$

where $K$ is the half-saturation coefficient, and $C_{i}$ is the nutrient concentration. $O_{i k}$ ranges from 0 to 1 . Since macrophytes usually use sediment as a nutrient supply, sediment plays an important role in macrophyte modelling.

We modified equation (5) in order to include the sediment influence, considering the equations proposed by Madden and Kemp ${ }^{13)}$. In the proposed model, both sediment and water nutrient uptakes have been included in the growth and nutrient uptake formulations:

$$
\begin{gathered}
f_{N}\left(N_{W}, N_{S}\right)=\frac{N_{W}+\frac{K_{W N}}{K_{S N}} N_{S}}{K_{W N}+N_{W}+\frac{K_{W N}}{K_{S N}} N_{S}} \\
f_{P}\left(P_{W}, P_{S}\right)=\frac{P_{W}+\frac{K_{W P}}{K_{S P}} P_{S}}{K_{W P}+P_{W}+\frac{K_{W P}}{K_{S P}} P_{S}}
\end{gathered}
$$

where $f_{N}\left(N_{W}, N_{S}\right)$ is the nutrient limitation function for nitrogen, $f_{P}\left(P_{W}, P_{S}\right)$ is the nutrient limitation function for phosphorus, $N_{W}$ is the total nitrogen water column concentration $\left(\mathrm{mg} \cdot \mathrm{l}^{-1}\right), N_{S}$ is the pore-water total nitrogen concentration $\left(\mathrm{mg} \cdot \mathrm{l}^{-1}\right), K_{W N}$ is the half-saturation constant for uptake of $N_{W}$ (shoots) $\left(\mathrm{mg} \cdot \mathrm{l}^{-1}\right) . K_{S N}$ is the half-saturation constant for the uptake of $N_{S}$ (roots) $\left(\mathrm{mg} \cdot 1^{-1}\right), P_{W}$ is the total phosphorus water column concentration $\left(\mathrm{mg} \cdot \mathrm{l}^{-1}\right), P_{S}$ is the pore-water total phosphorus concentration $\left(\mathrm{mg} \cdot \mathrm{l}^{-1}\right), K_{W P}$ is the half-saturation constant for uptake of $P_{W}$ (shoots) $\left(\mathrm{mg} \cdot \mathrm{l}^{-1}\right)$, and $K_{S P}$ is the half-saturation constant for the uptake of $P_{S}$ (roots) $\left(\mathrm{mg} \cdot \mathrm{l}^{-1}\right)$. Coefficients were obtained from controlled experiments and succesfuly applied to the modelling

\begin{tabular}{|c|c|c|c|}
\hline Parameter & Description & Value & Unit \\
\hline$P_{\max }$ & Maximum gross production rate ${ }^{1)}$ & 0.42 & $d^{-1}$ \\
\hline$H_{i}$ & Half saturation light limitation constant $\left.{ }^{2}\right)$ & 8.98 & $\mathrm{~W} \cdot \mathrm{m}^{-2}$ \\
\hline$K_{W N}$ & $\begin{array}{l}\text { Half saturation constant for the uptake } \\
\text { of } \mathrm{N} \text { from the shoots }{ }^{13)}\end{array}$ & 0.08 & $\mathrm{mg} \cdot \mathrm{l}^{-1}$ \\
\hline$K_{W P}$ & $\begin{array}{l}\text { Half saturation constant for the uptake } \\
\text { of } \mathrm{P} \text { from the shoots }{ }^{13)}\end{array}$ & 0.02 & $\mathrm{mg} \cdot \mathrm{l}^{-1}$ \\
\hline$K_{S N}$ & $\begin{array}{l}\text { Half saturation constant for the uptake } \\
\text { of } \mathrm{N} \text { from the roots }{ }^{13)}\end{array}$ & 1.4 & $\mathrm{mg} \cdot \mathrm{l}^{-1}$ \\
\hline$K_{S P}$ & $\begin{array}{l}\text { Half saturation constant for the uptake } \\
\text { of } \mathrm{P} \text { from the roots }{ }^{13)}\end{array}$ & 0.2 & $\mathrm{mg} \cdot \mathrm{l}^{-1}$ \\
\hline$R_{o}$ & Specific respiration rate at $20^{\circ} \mathrm{C}^{14)}$ & $0.001-0.05$ & $d^{-1}$ \\
\hline$Q_{10}$ & $\begin{array}{l}\text { Ratio of rates given a } 10{ }^{\circ} \mathrm{C} \text { change in } \\
\text { temperature }^{13)}\end{array}$ & 2.57 & - \\
\hline$\gamma$ & Maximum excretion rate ${ }^{1)}$ & 0.012 & $d^{-1}$ \\
\hline$L_{\text {sat }}$ & Irradiance at maximum production ${ }^{1)}$ & 152.36 & $\mathrm{~W} \cdot \mathrm{m}^{-2}$ \\
\hline$N$ & $\begin{array}{l}\text { Death rate of non-predatory } \\
\text { mortality }^{14)}\end{array}$ & $0.001-0.01$ & $d^{-1}$ \\
\hline
\end{tabular}
of different species of macrophytes ${ }^{13)}$.

Equation (2) changes as

$P\left(T, I, N_{W}, N_{S}, P_{W}, P_{S}\right)=P_{\max } T_{i}(T) L_{i}(I) f_{N}\left(N_{W}, N_{S}\right) f_{P}\left(P_{W}, P_{S}\right)(8)$ and values of $f_{N}\left(N_{W}, N_{S}\right)$ and $f_{P}\left(P_{W}, P_{S}\right)$ range from 0 to 1 .

Table 1 Parameter values of the model and their units. 
c) Respiration rate

Respiration rate can be calculated by the following equation:

$$
R=R_{o} Q_{10}{ }^{\frac{T-T_{o}}{10}}
$$

where $R$ is the respiration rate $\left(\mathrm{d}^{-1}\right), R_{o}$ is the specific respiration rate at a reference temperature of $20^{\circ} \mathrm{C}$, $T_{o}$ is the initial water temperature in ${ }^{\circ} \mathrm{C}, T$ is the final water temperature in ${ }^{\circ} \mathrm{C} . Q_{10}$ is the ratio of rates given a $10^{\circ} \mathrm{C}$ change in temperature ${ }^{14)}$.

\section{d) Excretion rate}

Excretion rate $E$ can be calculated by the following equation:

$$
\begin{gathered}
E=\gamma(1-L) \\
L=\frac{I}{L_{\text {sat }}} \exp \left[1-\left(\frac{I}{L_{\text {sat }}}\right)\right]
\end{gathered}
$$

where $\gamma$ is the maximum excretion rate, $L$ is the light limitation using Steele's light function to account for supraoptimal light intensity inhibition, $L_{\text {sat }}$ is the irradiance at maximum production obtained experimentally ${ }^{1)}$.

\section{e) Death rate}

The death rate of non-predatory mortality $N$ at post-maximal biomass ${ }^{14)}$ considered in this work is $0.01 \mathrm{~d}^{-1}$.

\section{RESULTS AND DISCUSSIONS}

\section{(1) Results}

\section{a) Aquatic vegetation and biomass}

Aquatic vegetation was mainly represented by macrophytes. The average values of macrophyte biomass in July (2012), February (2013) and August (2013) were $58 \mathrm{~g} \cdot \mathrm{m}^{2}, 154 \mathrm{~g} \cdot \mathrm{m}^{2}$ and $59 \mathrm{~g} \cdot \mathrm{m}^{2}$, respectively. Seasonal variations of the macrophyte biomass are shown in Fig.2.

\section{b) Physical parameters and nutrients in water and sediments}

Fig.3 shows monthly variations of measured discharge and solar radiation at the monitoring point P4 from July 2012 to August 2013. In this study, the average values of discharge during wet and dry season were: $0.41 \mathrm{~m}^{3} \cdot \mathrm{s}^{-1}$ and $0.24 \mathrm{~m}^{3} \cdot \mathrm{s}^{-1}$,

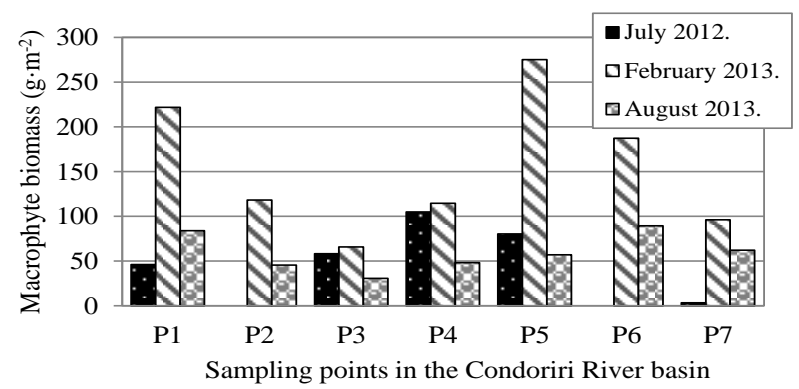

Fig.2 Species compositions of the biomass during dry and wet seasons: July (2012), February (2013), and August (2013) in the Condoriri River basin.
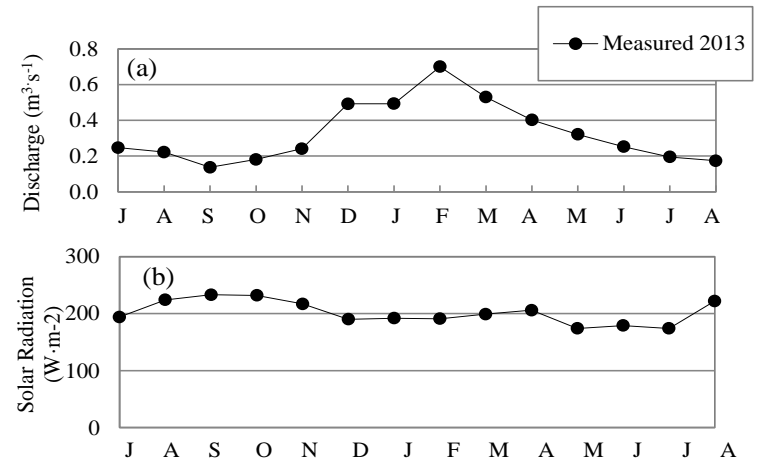

Fig.3 Monthly variations of measured data from July 2012 to August 2013: (a) discharge and (b) solar radiation at P4 in the Condoriri River basin.

respectively. The average values of solar radiation during wet and dry season were: $413 \mathrm{~W} \cdot \mathrm{m}^{-2}$ and 426 $\mathrm{W} \cdot \mathrm{m}^{-2}$, respectively. Water temperature varied from $2.1^{\circ} \mathrm{C}$ to $12.2^{\circ} \mathrm{C}$ in the dry season and from $2.3^{\circ} \mathrm{C}$ to $20.2^{\circ} \mathrm{C}$ during the wet season, due to the changes in the meteorological conditions in the basin ${ }^{7}$. Based on our observations and data from a previous study5), empirical relations were obtained for the estimation of water temperature and its variations with the distance from the edges of the glaciers. The relations are shown in Fig.4.

The average values and standard deviations of $\mathrm{TN}$ in water during wet season were $0.58 \pm 0.35$ $\mathrm{mg} \cdot \mathrm{l}^{-1}$ and during dry season were $0.37 \pm 0.07$ $\mathrm{mg} \cdot \mathrm{l}^{-1}$. TP was detectable only during the wet season $\left(0.015 \pm 0.009 \mathrm{mg} \cdot \mathrm{l}^{-1}\right)$, with a detection limit of $0.001 \mathrm{mg} \cdot 1^{-1}$. Based on these results, TN and TP were generally higher in the wet season than in the dry season. The average values and standard deviations of nitrogen in the sediments during wet and dry season were: $0.83 \pm 0.51 \%$ and $1.12 \pm$ $0.45 \%$, respectively. The average values and standard deviations for phosphorus in the sediments during wet and dry seasons were $0.033 \pm 0.030 \%$ and $0.034 \pm 0.018 \%$, respectively.

c) Specific discharge and specific transport of nutrients

The relations between the specific discharge vs. catchment area and the specific transport of total nitrogen and total phosphorus vs. specific discharge are shown in Fig.5. Average values of specific

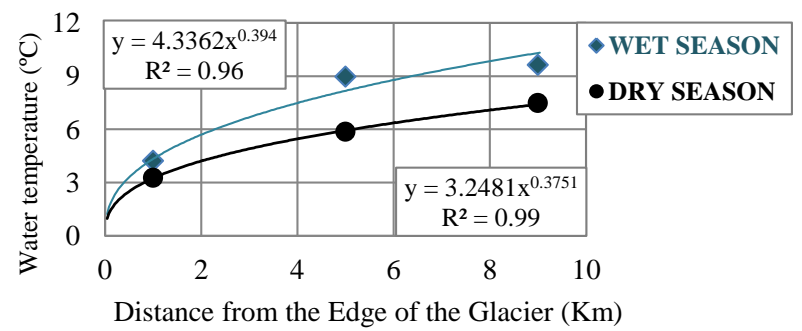

Fig.4 Variation of water temperature with the distance during wet and dry seasons in the Condoriri River basin. 

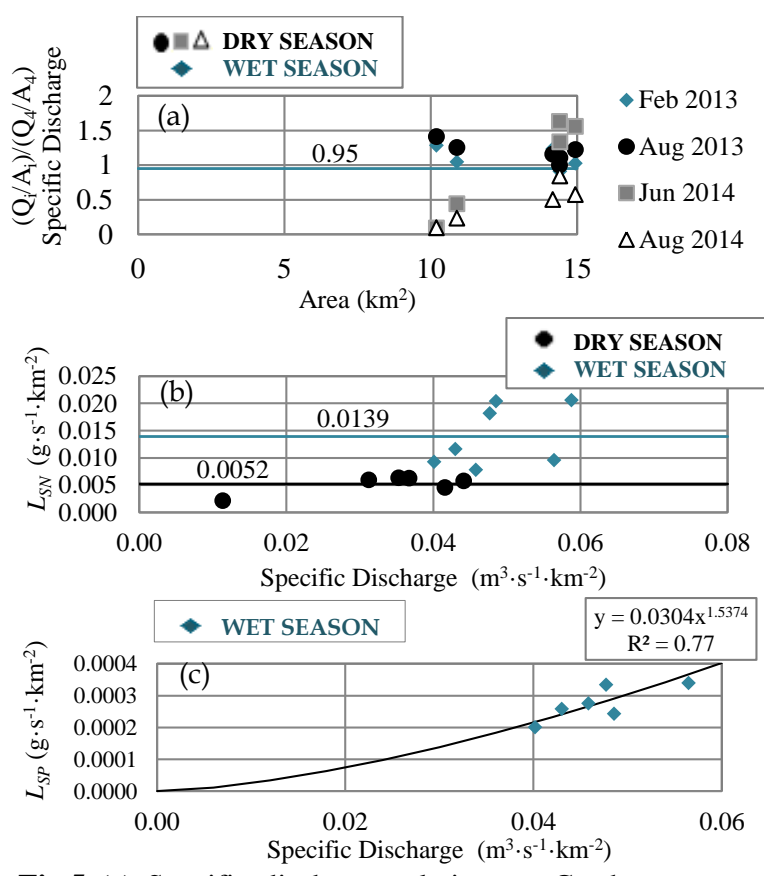

Fig.5 (a) Specific discharge relation vs. Catchment area, (b) Specific transport of TN vs. Specific discharge, and (c) Specific transport of TP vs. Specific discharge during wet season in the Condoriri River basin.

discharge and specific transport of nitrogen during dry and wet seasons were considered because of the variability of the measured data. Furthermore, an empirical relationship between the specific transport of phosphorus and specific discharge was established. With the previous considerations, we estimated the discharge and the concentrations of $\mathrm{TN}$ and TP at all the monitoring points in the basin. The following equations were used:

$$
Q=\frac{A}{A_{4}}(0.95) Q_{4}
$$

where $Q$ is the discharge $\left(\mathrm{m}^{3 \cdot} \mathrm{s}^{-1}\right)$ and $A$ is the catchment area covered at the monitoring point. $Q_{4}$ is the discharge $\left(\mathrm{m}^{3 \cdot} \mathrm{s}^{-1}\right)$ and $A_{4}$ is the catchment area
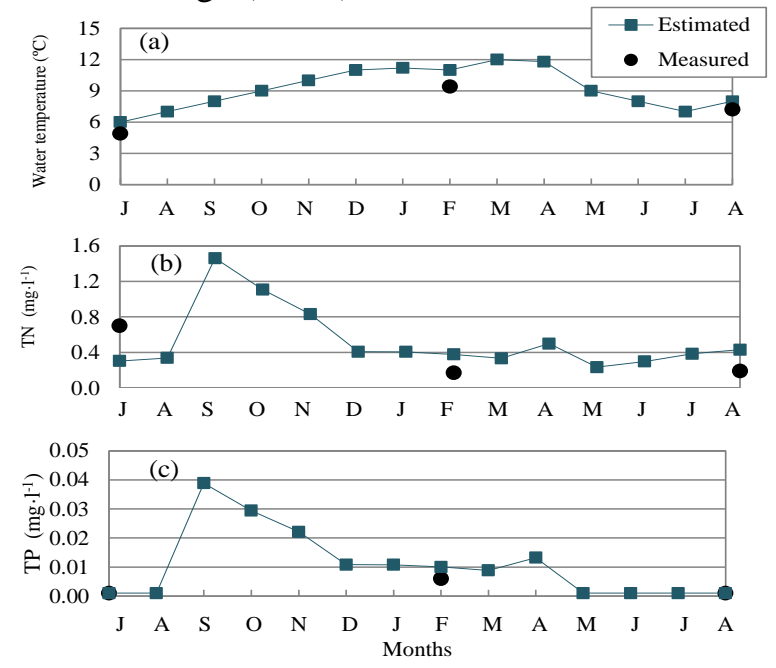

Fig.6 Comparison of estimated and measured data: (a) water temperature, (b) total nitrogen, and (c) total phosphorus at the monitoring point $\mathrm{P} 4$ in the Condoriri River basin. covered at P4. $Q_{4}$ was estimated with continuous air and water pressure data from the water level logger.

$$
\begin{aligned}
& N_{W}=\frac{A L s N}{Q} \\
& P_{W}=\frac{A L s P}{Q}
\end{aligned}
$$

where $A$ is the catchment area covered at the monitoring point, $L_{S N}$ is the specific transport of TN $\left(\mathrm{g} \cdot \mathrm{s}^{-1} \cdot \mathrm{km}^{-2}\right)$ and $L_{S P}$ is the specific transport of TP $\left(\mathrm{g} \cdot \mathrm{s}^{-1} \cdot \mathrm{km}^{-2}\right)$. Fig.6 shows the estimated values of water temperature, TN and TP compared with the measured data obtained in July (2012), February (2013) and August (2013).

\section{(2) Discussions}

\section{a) Predictions of the macrophyte model}

The developed macrophyte model predicted the
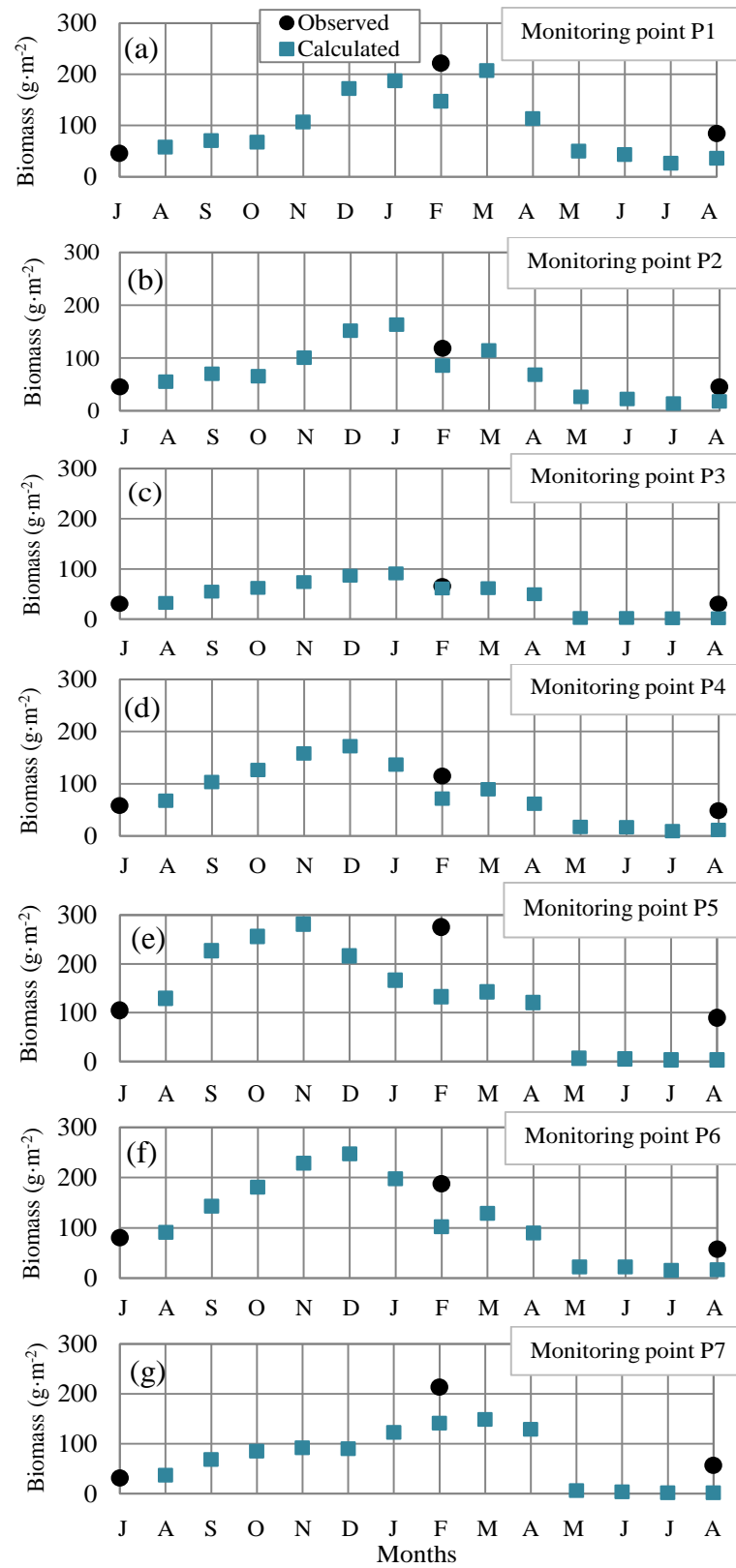

Fig.7 Modeled results and observed macrophyte biomass at all monitoring points in the Condoriri River basin. 
monthly variations of the growth of the aquatic plants in the Condoriri River basin. The results are shown in Fig.7. In the model results, the macrophyte biomass exhibited some variations from measurements especially at the monitoring points $\mathrm{P} 1$, P5, P6 and P7 during the wet season in February. This discrepancy between measurements and predictions seems to be caused by the increase of discharge in February as shown in Fig.3 (a). The greater discharge had a dilution effect on nutrient concentrations; consequently, the growth of the aquatic plants was affected in the model. Maximum biomass estimated by the model varied from November at P5 to March at P7, due to the changes of nutrients, water temperature and discharge, and their influence on the growth of the aquatic plants.

\section{CONCLUSIONS}

The macrophyte model presented in this study could lead to improved predictions of the macrophyte biomass variations under extreme seasonal variability which is the principal characteristic of the tropical glacier ecosystems. To summarize the above findings:

1) Good agreements have been achieved between field measurements and model predictions of macrophyte biomass at most of the monitoring points. However, the accuracy was low during wet season.

2) Specific nutrient loading was related to biomass increment. High specific transports of TN $(0.02$ $\left.\mathrm{g} \cdot \mathrm{s}^{-1} \cdot \mathrm{km}^{-2}\right)$ and TP $\left(0.0035 \mathrm{~g} \cdot \mathrm{s}^{-1} \cdot \mathrm{km}^{-2}\right)$ were measured during the wet season, likely to be caused by the extreme difference of the total precipitation (624 mm during rainy season and only $19 \mathrm{~mm}$ during dry season).

3) Our findings enhanced the understanding of the impacts of physical and chemical factors on the macrophyte growth. Although the prospects of accurate predictive simulation of aquatic vegetation are poor, especially during wet season, relatively simple models like the one presented can be a useful tool in improving the theoretical framework for understanding the dominant mechanisms regulating submerged plant dynamics. The results of this study can be used as baseline information for present and future modelling of the river system.

ACKNOWLEDGMENT: This study was supported by JST/JICA, SATREPS (Science and Technology Research Partnership for Sustainable Development) and JSPS KAKENHI (No. 24404015).

\section{REFERENCES}

1) Collins, C. D., \& Wlosinski, J. H.: A macrophyte submodel for aquatic ecosystems. Aquatic botany, Vol. 33, No. 3, pp.191-206, 1989.

2) Mulderij, G., Van Nes, E. H., \& Van Donk, E.: Macrophyte-phytoplankton interactions: the relative importance of allelopathy versus other factors. Ecological Modelling, Vol. 204, No. 1, pp.85-92, 2007.

3) Barko, J. W., Gunnison, D., \& Carpenter, S. R.: Sediment interactions with submersed macrophyte growth and community dynamics. Aquatic Botany, Vol. 41, No. 1, pp.41-65, 1991.

4) Vuille, M., Francou, B., Wagnon, P., Juen, I., Kaser, G., Mark, B. G., \& Bradley, R. S.: Climate change and tropical Andean glaciers: Past, present and future, Earth-Science Reviews, Vol. 89, No. 3, pp.79-96, 2008.

5) Tani, K., Umeda, M., Asaoka, Y., \& Yamazaki, T.: Field measurement and analysis on heat balance and water temperature formation in a high-altitude reservoir in the Bolivian Andes. Journal of Japan Society of Civil Engineers, Vol. 70, No. 4, pp. 1627-1632, 2014.

6) Moya Quiroga, V., Mano, A., Asaoka, Y., Udo, K., Kure, S., Mendoza, J.: Hydrological Modelling of a Glacierized Andean Basin Using the Semi Distributed Model Supertank. Case: the Andean Basin Condoriri. Proc. Congr. Int. Assoc. Hydraul. Res.388, 2013.

7) Sicart, J. E., Wagnon, P., \& Ribstein, P.: Atmospheric controls of the heat balance of Zongo Glacier (16 S, Bolivia), Journal of Geophysical Research, Vol.110, 2005.

8) Malik, D. S., \& Joshi, N.: Distribution pattern of aquatic macrophytes and their biomass in relation to some nutrients in Asan wetland, India, Inter. J. for Environmetal Rehabilitation and Conservation, Vol. 4, No. 1, 2013.

9) Van Reeuwijk, L.P.: Procedures for Soil Analysis, Technical Paper. International Soil Reference and Information Centre, Wageningen, Vol. 19, No. 3, 1992.

10) Scheffer, M., Bakema, A. H., \& Wolterboer, F. G.: MEGAPLANT: a simulation model of the dynamics of submerged plants. Aquatic Botany, Vol. 45, No. 4, pp.341-356, 1993.

11) Van Nes, E. H., Scheffer, M., van den Berg, M. S., \& Coops, H.: Charisma: a spatial explicit simulation model of submerged macrophytes. Ecological Modelling, Vol. 159, No 2, pp. 103-116, 2003.

12) Wolfer, S. R., Van Nes, E. H., \& Straile, D.: Modelling the clonal growth of the rhizomatous macrophyte: Potamogeton perfoliatus. Ecological modelling, Vol. 192, No 1, pp. 67-82, 2006.

13) Cerco, C. F., \& Moore, K.: System-wide submerged aquatic vegetation model for Chesapeake Bay. Estuaries, Vol. 24, No. 4, pp.522-534, 2001.

14) Ambrose, R. B., Wool, T. A., \& Martin, J. L.: The water quality analysis simulation program, WASP5, Part A: Model documentation. Environmental Research Laboratory, US Environmental Protection Agency, Athens, GA, 1993.

(Received September 30, 2014) 